\title{
Assessing Language for Literacy: A Microanalysis of Children's Vocabulary, Syntax and Narrative Grammar
}

\author{
Janet Scull ${ }^{1}$ \\ ${ }^{1}$ The University of Melbourne, Victoria, Australia \\ Correspondence: Janet Scull, Melbourne Graduate School of Education, The University of Melbourne, Victoria, \\ 3010, Australia. Tel: 61-383-448-348. E-mail: j.scull@unimelb.edu.au
}

Received: October 18, 2012 Accepted: October 30, 2012 Online Published: December 10, 2012

doi:10.5539/ies.v6n1p142

URL: http://dx.doi.org/10.5539/ies.v6n1p142

\begin{abstract}
This paper examines the oral language resources that enhance children's reading and comprehension processes. Using data from a study of 16 children, the microanalysis of the three more successful readers, identified salient factors from the individual children's learning profiles that were observed as associated with their positive comprehension outcomes. The results indicate vocabulary knowledge, syntactic competence and an understanding of narrative grammar as important to the concurrent development of children's oral language abilities commensurate with text reading. The study emphasises the facilitative role of oral language to early reading acquisition processes, the need for teachers' detailed knowledge of children's oral language competencies and improved access to assessment tools that capture a range of complex language skills to inform classroom practice.
\end{abstract}

Keywords: oral language, assessment, early literacy

\section{Introduction}

It is through an increasing control over the features of spoken expression that children are able to share ideas and communicate what they know. As Vygotsky's (1978) theory suggest children's learning is most affected by semiotic mediation and it is through the use and manipulation of language forms that children gain the signs and symbols to think about and respond to the world (Tracey \& Morrow, 2006). As children learn ideas are formed and coded through language, and "an ability to both demonstrate and rework ideas is integral to the educative process" (Raban, 1999, p. 103). While these views account for the contribution of language to learning more generally, it is ever more apparent that children's oral language resources impact on reading acquisition and comprehension processes (Clay, 2001; Dickinson \& Porche, 2011; Gee 2004: Snow, 1991). Hence it is important that teachers know what aspects of language matter to reading and how these might be assessed to subsequently support children's language learning facilitative of reading development.

\section{Oral Language Facilitative of Reading}

The National Early Literacy Panel Report Developing Early Literacy (2009) found that some aspects of oral language were clearly more related to later literacy outcomes than others. Specifically this report notes "complex aspects of oral language, such as grammar, definitional vocabulary, and listening comprehension, as having more substantial predictive relations with later conventional literacy skills" (p 78). Likewise, the National Institute of Child Health and Human Development (NICHD) Early Child Care Research Network (2005) suggest that "oral language conceptualized broadly plays both a direct and an indirect role in word recognition during the transition to school and serves as a better foundation for early reading skill than does vocabulary alone" (p.428). Snow, Burns and Griffin refer to children's "overall language ability" $(1998, p .111)$ as related to literacy learning. Particularly, children's expressive and receptive vocabulary, the ability to recall and comprehend sentences and stories, and the ability to engage in extended, connected verbal discourse as predictive of early reading ability (Snow et al., 1998). Based on the evidence accumulated for a more broadly conceptualised language base for reading, three areas recur as the focus for learning - vocabulary development, syntactical competence and understandings of narrative grammar. 


\subsection{Vocabulary Development}

Vocabulary development is widely regarded as central to reading comprehension. Vellutino and colleagues (2007) report "vocabulary and other types of semantic knowledge as important determinants of language and reading comprehension skills in early and late-stage readers" (p. 26). Pearson, Hiebert and Kamil (2007) make a strong claim for the predictive power of vocabulary, they state "there is no doubt that vocabulary is closely tied to comprehension...in study after study, vocabulary knowledge predicts comprehension performance with positive correlations" (p. 282). Similarly, Biemiller (2011) asserts that Grade one general vocabulary is a strong predictor of reading comprehension in grade 11 . The significance of vocabulary knowledge, as it relates to comprehension processes, is also emphasised in studies by Freebody and Anderson (1983) and Beck and McKeown (1991; 2001). Likewise, Stanovich (1986, p. 379) argues:

There is a growing body of data indicating that variation in vocabulary knowledge is a causal determinant of difference in reading comprehension abilities...the relationship is one that continues throughout reading development and remains in force for even the most fluent adult readers.

Evidence from longitudinal studies also support the claim that children's early language learning has long term effects on children's reading comprehension. Findings from The Home School Study of Language and Literacy Development (Dickinson \& Tabors, 2001) emphasise both vocabulary development and decontextualised, extended language forms as predictive of enhanced later reading performance. Descriptive information from this research indicates that a child's exposure to a full and varied vocabulary as early as age four is a powerful predictor of later literacy growth. Further, children with stronger language skills were more likely to engage in interesting conversations with their preschool teachers, and these conversations contributed favourably to children's ongoing literacy development (Dickinson \& Porche, 2011).

\subsection{Syntactic Competence}

There is also research that proposes reading comprehension is facilitated when materials contain high-frequency syntax patterns from children's oral language (Eskey, 1986; Griffin, Hemphill, Camp \& Wolf, 2004; Snow et al., 1998). In addition, these studies allude to the possibility that a beginning reader's experience with spoken discourse may be insufficient to support the effective processing and comprehension of written texts. Hence, some of the features of the grammatical organisation of written discourse may impede children's comprehension. As Leu (1982, p. 124) states:

Young children's knowledge of linguistic organization apparently reflects their largely oral language experiences. Relatively unfamiliar with the syntactic probabilities of written discourse, their hypotheses about upcoming text are often determined by an inappropriate set of expectations. Hypotheses based on the syntactic probabilities of oral discourse often conflict with the more integrated patterns of written discourse. As a result, comprehension suffers.

From a curriculum and teaching-practice perspective, it becomes imperative that young readers' oral discourse experiences provide sufficient information about the organisation of written texts to ensure their efficient processing and understanding. In turn, this requires teachers to attend to the use of more complex syntactical variations (Huttenlocher, Vasilyeva, \& Shimpi, 2004; Vasilyeva \& Waterfall, 2012), moving beyond conversational exchanges to supporting children to experience and use language in a range of forms and for a variety of purposes (Raban, 1999). Increasing children's syntactic proficiency to support early literacy (Clay, 2001; Raban, 2000) may also have a broad effect on school performance more generally (Vasilyeva, Huttenlocher \& Waterfall, 2006).

\subsection{Understanding Narrative Grammar}

Children's ability to produce oral narratives encompasses a range of complex language skills and is considered an important predictor of later language and literacy development (Lever \& Sénéchal, 2011; Paris \& Paris, 2003; Riley \& Burrell, 2007). Many children as young as two to three years old develop a rich repertoire of knowledge about narrative, and become increasing skilled at understanding and producing narrative stories, matched to their home languages and cultural practices (Bliss \& McCabe, 2008; Heath, 1983). These narratives are thought to be a form of literate language that serves as a bridge between oral and written language, with the knowledge of story schemas believed to be important for reading comprehension (Westby, 2005). Paris and Paris (2003, p.40) describe "early narrative competence is a fundamental aspect of children's comprehension of experiences before they begin to read, as it helps children map their understanding onto texts". Building an understanding of story schema that aids recall and supports comprehension (Stevens, Van Meter \& Warcholak, 2010). 
More specifically, Lever and Sénéchal (2011,p.2) report "correlational studies that suggest early narrative skills are related to children's later literacy development, with moderate to strong relations existing between the production of fictional narratives and concurrent, as well as future, reading comprehension". In addition, the Home School Study, found oral narrative production among predictor variables with consistent significant and strong correlations to fourth- and seventh- grade reading comprehension (Dickinson, McCabe, Anastasopoulos, Peisner-Feinberg \& Poe, 2003; Tabors, Snow, \& Dickinson, 2001).

Based on the evidence reported above, of relationships between children's language development and text comprehension, the current study intended to explore observed associations between these areas of language and literacy learning. Specifically, it aimed to consider the oral language skill sets of children who demonstrated proficiency in reading comprehension in the early years of schooling.

\section{Case Studies of Children's Language and Reading}

The purpose of the case studies presented in this paper is twofold. First they demonstrate how the aspects of oral language described above map with children's reading comprehension and second they provide details of the assessment tasks that gave clear insights into children's language skills.

\subsection{Study Context, Case Study Selection and Assessment Measures}

The case studies reported in this paper are extracted from a larger study that examined the reading development of 16 children participating in Reading Recovery (Clay, 2001). Children selected for Reading Recovery are typically in their second year of school and falling behind their classmates, as they have not yet acquired effective reading and writing processes. The teachers in this study had all undertaken extensive professional training to develop their understandings of reading acquisition processes and were skilled in the design of teaching programs to support effective reading skills and strategies. The training ensured that the teaching was consistent across the larger sample and while all children showed increased reading abilities as measured by texts graded for difficulty, only the children profiled here showed strong evidence of text comprehension with reading age scores equivalent to or above their chronological age at the time of testing.

The study was performed with approval from the University's Human Research Ethics Committee. According to the information requirement all teachers and parents were informed of the study's purpose and design and gave their consent to participate in writing. Pseudonyms are used to support the confidentiality obligations.

The following measures were administered to assess children's language and reading abilities.

\subsection{Woodcock Oral Vocabulary and Verbal Analogies Tests}

These tests were taken from the Woodcock Language Proficiency Battery (Revised), a set of tasks designed to measure children's achievement in oral language, reading and written language (Woodcock, 1991). The Oral Vocabulary Test measures knowledge of word meanings. In Part A of the test, stimulus words are presented and children are requested to offer a synonym for the target word. In Part B children are required to state an antonym for the stimulus word. It was intended to use the data of oral vocabulary as an indicator or as evidence of children's expressive vocabulary (Woodcock, 1991, p. 10). The test of Verbal Analogies measures the ability to comprehend and verbally complete a logical word relationship. To be successful the children must discern the inherent relationship or association among the words and retrieve an appropriate response (Woodcock, 1991, p. 10).

\subsection{Tell Me: A Collaborative Language Activity}

Tell Me, developed by Stuart McNaughton, forms part of the School Entry Assessment (SEA) kit (Curriculum Corporation, 1999). It involves children retelling stories, using set texts, to assess the comprehension and language skills they use to organise a narrative and relate events in a descriptive and expressive way. The task builds on familiar and meaningful storytelling activities and assesses how well a child performs with teacher guidance. The assessment procedure begins with the reading of a story and the child is then asked to retell the text. Using a four-point scale the children's control over sentence complexity; vocabulary; text organization; descriptions /expression and content accuracy is assessed. The Tell Me procedure was administered to all participating children on two occasions when a different text from the Tell Me kit was used; first the children retold the text Bernard O'Brien's Tooth (Noonan, 1999) with the text The New Baby (Anderson, 1999) selected as the second text. The two texts were selected for children familiarity with the experiences and concepts within them. It was not the purpose of this test to include new concepts and ideas, but to gauge how well the children were able to use language to express ideas represented in the texts. 


\subsection{Record of Oral Language}

The Record of Oral Language (Clay, Gill, Glynn, McNaughton \& Salmon, 2007) was designed to give insight into the ways young children master the different structures found in English sentences. The assessment grades sentences to "describe the most advanced structural level of oral language which a child might listen to with full understanding" (Clay et al., 2007, p. 11). Items included in this test have been assessed by statistical measures, applied to standardised tests, to establish the reliability of item difficulty across different groups of children. Research studies conducted in the USA indicate that the test discriminates well among children of five to seven years of age who speak English as a first language (Clay et al., 2007). The measure engages the children in a sentence repetition task. The test uses 42 sentences, grouped according to three levels of difficulty and includes seven different sentence types.

\subsection{PROBE Reading Assessment}

As a specific measure of comprehension, the Prose Reading Observation and Evaluation of Comprehension (PROBE) was used. (Parkin, Parkin \& Pool, 2002). The test provided passages graded to children's chronological age across 12-month age bands. As a measure of comprehension, the test requires children to read a series of graded passages and respond to a range of question types to assess their level of understanding. Children's reading accuracy and comprehension scores are combined to provide a Reading Age (RA).

\section{Case Study One: Remy}

Remy was aged 7 years 5 months (numeric 7.4) when the PROBE (Parkin et al., 2002) reading test was administered, and he had a Reading Age (RA) of 7.5 for fiction passages. Acknowledging the complexity of experiences and understandings children bring to reading acquisition and reading tasks more generally, Remy's strong oral language skills are identified as contributing to his ability to construct meaning from print and interpret text messages. Two aspects of oral language are highlighted in Remy's skill profile: vocabulary knowledge and control of the grammatical structures of language. An examination of his test scores, listed in Table 1, indicate that Remy scored 39 for the Record of Oral Language (Clay, et al., 2007) and had an age equivalent of 8.2 for the Woodcock Oral Vocabulary Test (Woodcock, 1991).

Table 1. Oral language test results for Remy

\begin{tabular}{ll}
\hline Test & Score/s \\
\hline Record of Oral Language & 39 \\
Tell Me & Text $1-16$ and Text $2-16$ \\
Woodcock Oral Vocabulary & Raw score 16 (Age equivalent 8.2) \\
Woodcock Verbal Analogies & Raw score 6 (Age equivalent 6.8) \\
\hline
\end{tabular}

The Woodcock Oral Vocabulary Test requires children to supply synonyms and antonyms for set words. In contrast to other children in this study, who found the task requiring the provision of synonyms particularly difficult, Remy responded correctly to six stimulus words, compared with the median score of two. Remy was able to supply synonyms for items such as 'begin', 'we' and 'lawn'. It appears from this data set that Remy was able to draw on a rich and varied knowledge of vocabulary to support his understanding of written language.

Complementing Remy's knowledge of vocabulary is his control over the syntactical patterns of English. He was able to produce grammatically correct responses for all Record of Oral Language stimulus sentences, with his three errors assessed as grammatical alternatives to the more difficult Level 3 sentences. For example, in response to the stimulus "The girl saw who her mother was giving the cakes to" Remy supplied "The girl saw who my mother was giving the cakes to".

Further evidence of his control over the syntax of language is demonstrated in his text retellings. The sentences below from his retelling of The New Baby (Anderson, 1999) demonstrate the use adverbial phrases of time and place, contrastive conjunctions that result in embedded clauses and appropriate pronoun reference chains.

Transcript 1: Remy retelling The New Baby

Page $6 \& 7$

And then Dad came outside and said that their mum was going to have her baby very soon so they [sic] he had to take her to the hospital. And then they both kissed their mother. 


\section{Page 8}

The next morning they asked their dad if they had um if she had a baby and then dad said "let's wait and see".

Remy's oral language skill profile resonates well with research that reports children's oral language as a resource for reading. Specifically, the ability to control the more complex linguistic structures supportive of reading comprehension is well documented (Gee, 2004; Leu, 1982; Perfetti, 1990). Remy's comprehension and language test results suggest that his syntactic competence allowed him to effectively assess the grammatical alternatives and restrictions of written text and to construct an interpretation of what has been read (Gee, 2004; Leu, 1982).

\section{Case Study Two: Elizabeth}

Elizabeth was aged 6 years 11 months (numeric 7.0) when the PROBE test was administered and had a RA equivalent to her chronological age. Her oral language results, detailed in Table 2, show that her test scores were largely in the average range for the study's cohort. However like Remy, Elizabeth was able to draw on a strong understanding of word meanings to support her reading. Highlighted here is her Verbal Analogies Test (Woodcock, 1991) score.

Table 2. Oral language test results for Elizabeth

\begin{tabular}{ll}
\hline Test & Score/s \\
\hline Record of Oral Language & 34 \\
Tell Me & Text $1-11$ and Text $2-14$ \\
Woodcock Oral Vocabulary & Raw score 12 (Age equivalent 6.8) \\
Woodcock Verbal Analogies & Raw score 12 (Age equivalent 9.3) \\
\hline
\end{tabular}

The Woodcock Verbal Analogies Test was particularly challenging for children in this study, with a median score of 6.5 obtained for this task. Elizabeth's raw score of 12 equates to an age-equivalent score of 9.3, which is 3 years and 2 months above her chronological age at the time of testing. Elizabeth's responses to this task demonstrated her ability to interpret language and relate ideas, examples of her control over word meanings was illustrated in her successful responses detailed below.

Item $7 \quad$ Can is to metal as bottle is to glass

Item 9 Cut is to hair as mow is to lawn

Item 18 Movie is to actor as game is to player

The data reported here reflect observations of the role of word meanings as a resource for reading, as well as empirical research findings of the role of vocabulary knowledge as a support for children's understanding of printed texts (Beck \& McKeown, 1991, 2001; Dickinson \& Tabors, 2001; Freebody \& Anderson, 1983; Stanovich 1986) Elizabeth clearly demonstrated her competency in this area, interpreting word meanings and manipulating language through the use of analogy.

Importantly this knowledge of vocabulary provided a resource for Elizabeth to comprehend and talk about text. The transcript below is illustrative of her receptive and productive vocabulary skills. As a participant interlocutor she was able to demonstrate a clear understanding of events in the text. Her contributions to the discussion included use of the synonym 'gaol' to indicate understanding the word prompts 'prison' and 'cells' supplied by her teacher. She also used 'slither' to describe the movement of the caterpillar and 'definitely' to respond in the affirmative to her teacher's suggestion.

Transcript 2. Elizabeth discussing The Trouble with Grandad (Cole, 1988)

T: Do you think, turn the page and see if the problems over.

C: $\quad$ Oh no no no.

T: What do you think?

C: $\quad$ There's the big caterpillar now.

T: That's right it's a big caterpillar and it went to sleep on top of the police station and all the other prisoners broke out of the cells. 


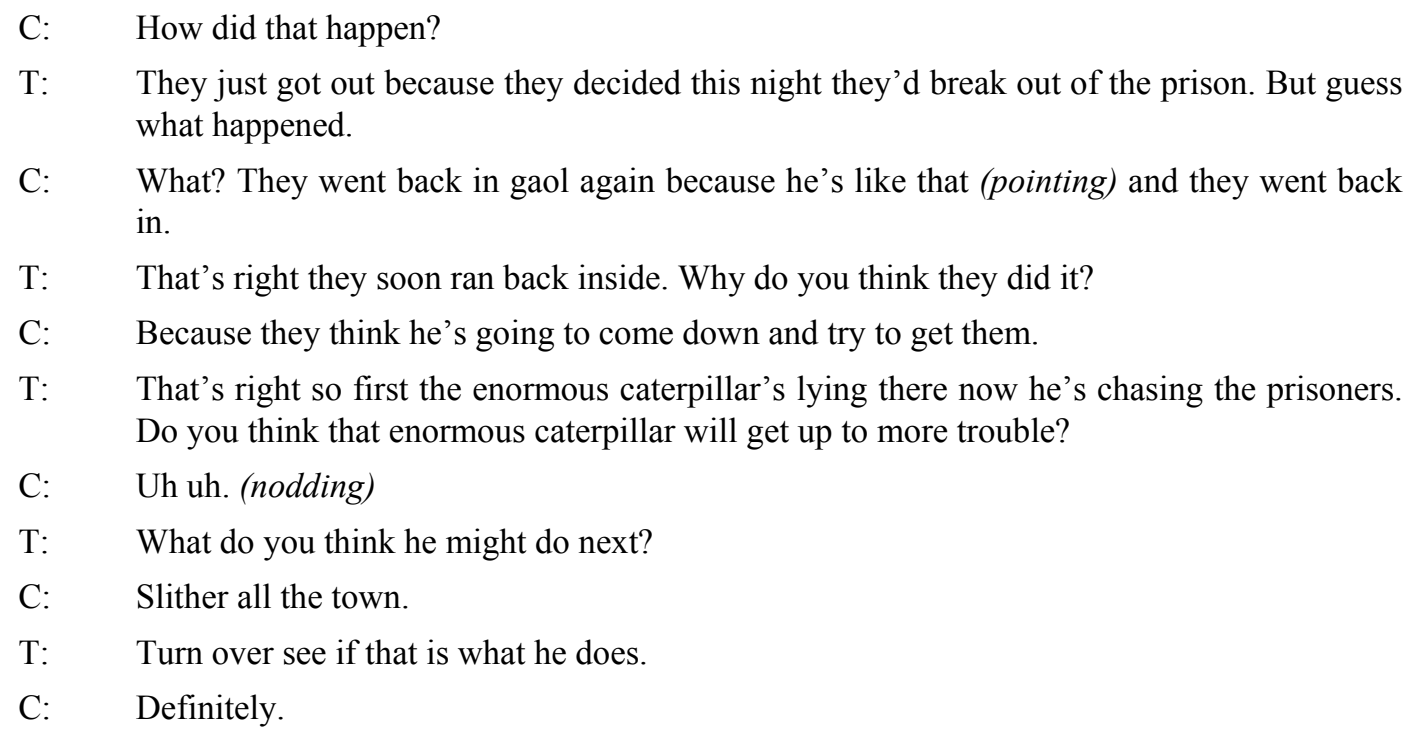

In many ways Elizabeth's oral language skill profile reflected those of Remy, reinforcing flexible control over language with effective literacy acquisition processes.

\section{Case Study Three: Michael}

Michael was aged 6 years 10 months (6.9 numeric) when the PROBE test was administered and he had a RA of 8.0 for fiction passages. An analysis of Michael's data adds to the collective evidence detailed in these case studies of the determinative role of language as facilitative of reading, see Table 3. His score of 36 for the Record of Oral Language (Clay et al., 2007) indicated a strong command of English syntax. In addition, his Woodcock language test scores (Woodcock, 1991) were above his chronological age, revealing vocabulary competence supportive of reading (Beck \& McKeown, 2001; Stanovich 1986). Complementing these two data sets, Michael's Tell Me (Curriculum Corporation, 1999) scores provided further evidence of his control over vocabulary, sentence structure and story grammar.

Table 3. Oral language test results for Michael

\begin{tabular}{ll}
\hline Test & Score/s \\
\hline Record of Oral Language & 36 \\
Tell Me & Text $1-15$ and Text 2 -17 \\
Woodcock Oral Vocabulary & Raw score 13 (Age equivalent 7.0) \\
Woodcock Verbal Analogies & Raw score 7 (Age equivalent 7.2) \\
\hline
\end{tabular}

Michael's retelling of the two Tell Me texts provided insight into his ability to orchestrate oral language for particular purposes related to text comprehension. The criterion referenced scores for his retellings indicated a superior control of oral language, as illustrated in the transcript of his retelling of Bernard O'Brien's Tooth. Specifically noted here is Michael's oral language ability that allowed him to retell the text with accuracy and precision.

Transcript 3: Michael retelling Bernard O'Brien's Tooth.

Page 3

He was wiggling his tooth trying to get this tooth out because it was so wobbly.

Page 4

His mum got the pliers out and tried to pull it out.

Page 7

His dad grabbed his legs and shaked him.

Page 8 and 9 
The brother tied a string onto his tooth and he was going to tie the string onto the door handle and shut it so that it can come out.

Page 11

Then he brushed his teeth and his tooth fell out and went plop into the water.

Page 12

Then when his tooth came out he picked it up from the water and he said "everyone come and look at my tooth".

This transcript highlights Michael's clear understanding of story grammar. Key narrative components characters, problem, attempted solutions, and solution - are articulated (Stevens, et al., 2010). His retelling reinforces skills that support the understanding of text, as he identified story elements that connect the entire narrative (Paris \& Paris, 2003). This is where it is presumed that Michael's language and reading comprehension competencies intersect. His ability to use a number of language skills (syntax, semantics, and narrative grammar) to convey a story to a listener are resources also available to assist his construction of meaning and to share ideas gleaned from written texts. As Clay (2004, p. 4) argues:

When we speak or listen to speech, we are constructing and composing; when we write any message, we are constructing and composing; and when we read text, we are again constructing and composing. The demands of each of these three activities are slightly different but each feeds into one pool of structural possibilities in the language.

Importantly, these responses reiterate the findings of the two previous case studies in highlighting the central role of oral language to reading. Michael's oral language competence was seen as assisting his comprehension of texts and his expression of these understandings.

\section{Discussion}

The analysis of children's oral language and reading profiles raises a number of issues for consideration alongside implications for practice. These are discussed in the section that follows.

\subsection{The Role of Language in a Complex Model of Reading}

When children are learning to read and building confidence and skill they need to use all the resources available to them. Particularly when the goal of reading is to engage in text meanings, not simply to recognize words rapidly (Harrison, 2004). As demonstrated in three case studies reported, for beginning readers, language-based sources of information are critical. In addition to a "working understanding of how sounds are represented alphabetically, they require sufficient background knowledge and vocabulary to render written texts meaningful and interesting, control over procedures for monitoring comprehension and repairing misunderstandings, and continued interest and motivation to read for a variety of purposes" (Snow, Burns \& Griffin, 1998, executive summary). In interactive models of reading readers draw on a range of information in sources, extending their searching and linking systems to construct complex operating systems to effectively process and comprehend texts (Clay, 2001; Rumelhart, 1994; Singer, 1994). Knowledge of language is a primary source of information young readers attend to, and continues as strong influence over children's reading acquisition and developmental processes (Clay 1991; 2001).

\subsection{The Need for a Clear, Understanding of Children's Language Competencies}

Data from the present study contributes to an evidence base that positions complex language skills as an important factor related to reading achievement, with effective early literacy teaching reliant on having detailed knowledge about children's oral language skills. However, oral language can be difficult to assess, making it hard for teachers to accurately describe children's competency and progress. This is attributed to the ephemeral nature of spoken language; teachers' knowledge of language and the availability of assessment measures that teachers feel confident using and interpreting (Riley \& Burrell, 2007). Substantial knowledge of language and language development is necessary to make accurate, informed judgments about children's overall language abilities including the more complex aspects of language foundational to text comprehension. Riley's and Burrell's (2007) evaluation of the Tell Me task indicated that teachers lacked confidence assessing the 'nuances of language' and they expressed the need for further practice and opportunities to work with others in scoring and administering the test. This points to the need for professional development and revised teacher training programs to enhance teachers' knowledge base in this key area of assessment and learning.

Similarly there is a need for test design that captures complex aspects of language in ways that increase teachers' knowledge of children's oral language skills and fits with classroom practice. The relevance of the information, congruence with the curriculum and the demands on teachers' time are factors for consideration. There are 
currently a variety of language tests available however many focus on a single area of learning or require specialised qualifications for administration. In this study, three different measures were used to capture children's language. Preferable would be one integrated task that assessed children's receptive and productive language, supported teachers' analysis of the results, with strong connections to language and literacy pedagogy. Features of such a measure should include processes for systematic observation of children across a range of authentic tasks (Clay, 2002). Further, as formative assessment, the data produced would be available for teachers to make sensitive inferences about children's progress to inform their teaching (Black \& Wiliams, 1998).

\subsection{Classroom Opportunities to Support Language Development}

In addition to authentic assessment, the case studies signal a need to focus on oral language teaching complementary to reading comprehension. Providing experiences for children to hear and use written language structures, expand their vocabulary and develop familiarity with story grammars corresponding to those of the texts they might be expected to read. Book reading and talk about text is an obvious context for this learning. In addition to the well-documented impact of book reading to vocabulary development (Beck \& McKeown, 2001; Dickinson, Griffith, Golinkoff \& Hirsh-Pasek. 2012) the structural variations introduced in texts develop a familiarity that allows the reader to handle complex language with growing facility (Cazden, 1982), alongside building awareness of story schema. As children retell texts they pay close attention to narrative elements and provide a description of the relationship across these elements. Importantly, as a stimulus for talk, texts invite dialogue, expand lexical and grammatical competence and provide contexts for language use.

Book discussions with the case study children and teachers highlighted opportunities to use the language of text in oral discourse. Despite these texts being graded for difficulty, they allowed children to incorporate relatively rare vocabulary and to explore the syntactic rules associated with narrative texts. In elaborating the results of the present study, of particular relevance is children's active involvement in discussions. The teachers demonstrated skill in engaging the children as active participants in teaching conversations, modelling ways to articulate responses to texts and scaffolding interactions to promote discussion (Hughes \& Westgate, 1998; Palincsar, 1998; Scull, 2010).

\section{Limitations}

The limitations of this research reside in the nature and design of this study. The research was constrained by the focus on a small group of children working with eight teachers to develop portraits of the children's language and reading skills. The findings concern these children and their specific learning needs; in particular, the central importance of oral language as it contributes to early literacy learning. Further investigation of children's oral language use and development is needed to make clearer this relationship in an effort to enhance literacy learning opportunities for children, particularly those identified as needing additional literacy learning support. Nevertheless, as learning to read is commonly experienced, it can be assumed that children of a similar age and in similar learning contexts are likely to exhibit comparable skills that translated to better comprehension outcomes. A larger scale replication of this research would test the reliability of the findings and this assumption.

Further, future research is also required to test the associations explored in this paper and examine the relationships between measures of oral and language and reading comprehension. A larger study, incorporating data testing a model of associations with causal links, is needed to test any assertions of predication and correlation.

\section{Conclusion}

The three case studies identified the children's superior oral language skills and despite their having specific strengths in different skills areas, as measured by the range of tests administered, each demonstrated oral language competencies alongside an ability to construct meaning from written text and to articulate these understandings. The findings suggest an early years literacy pedagogy that integrates oral language and reading instruction. Specifically, with opportunities for children to master more intricate forms of language and build a syntactic base commensurate with the structural complexity of written discourse; enhance their range of lexical choices; and develop their ability to narrate oral stories that recall real or imagined events in ways that draw meaning from experiences and texts read. This presents a challenge as it requires teachers to develop a profound knowledge of oral language acquisition and developmental processes and to have access to assessment tools that allow them to make constructive decisions to inform their teaching. However, given the available substantial evidence of the associations between language and literacy, it is important to examine ways teachers can build on this research to improve the ways they monitor children's oral language competence to afford enhanced literacy teaching and learning. 


\section{References}

Anderson, K. E. (1999). The new baby. Wellington: Learning Media.

Beck, I. L., \& McKeown, M. G. (1991). Conditions of vocabulary acquisition. In R. Barr, M. L. Kamill, P. B. Mosenthal \& P. D. Pearson (Eds.), Handbook of reading research, (Vol. 2, pp. 789-814). White Plains NY: Longman.

Beck, I. L., \& McKeown, M. G. (2001). Text talk: Capturing the benefits of read-aloud experiences for children. The Reading Teacher, 55, 10-20.

Biemiller, A. (2011, Winter). Vocabulary: What words should we teach? Better evidence-based education. Johns Hopkins University School of Education Center for Research and Reform in Education, pp.10-11.

Black, P., \& Wiliams, D. (1998). Assessment and Classroom Learning. Assessment in Education, 5, 7-74. http://dx.doi.org/10.1080/0969595980050102

Bliss, L. S., \& McCabe, A. (2008). Personal narratives cultural differences and clinical implications. Topics in Language Disorders, 28, 162-177. http://dx.doi.org/10.1177/0013124510392567

Cazden, C. B. (1982). Contexts for literacy: in the mind and in the classroom. Journal of Reading Behavior, 14, 413-427.

Clay, M. M. (1991). Becoming literate: The construction of inner control. Auckland: Heinemann.

Clay, M. M. (2001). Change over time in children's literacy development. Auckland: Heinemann.

Clay, M. M. (2002). An observation survey of early literacy achievement. Auckland: Heinemann.

Clay, M. M. (2004). Talking, reading and writing. Journal of Reading Recovery, Spring, 1-15.

Clay, M. M., Gill, M., Glynn, T., McNaughton, T., \& Salmon, K. (2007). Record of oral language: Observing changes in the acquisition of language structures. Auckland: Heinemann.

Cole, B. (1988). The trouble with grandad. London: Treasure Press.

Curriculum Corporation. (1999). School Entry Assessment (SEA). Wellington, N.Z.: Learning Media for Curriculum Corporation.

Dickinson, D. K., \& Porche, M. V. (2011). Relation between language experiences in preschool classrooms and children's kindergarten and fourth-grade language and reading abilities. Child Development, 82, 870-886. http://dx.doi.org/10.1111/j.1467-8624.2011.01576.x

Dickinson, D. K., \& Tabors, P. O. (2001). Beginning literacy with language: Young children learning at home and school. Baltimore, MD: Paul H. Brookes.

Dickinson, D. K., Griffith, J. A., Golinkoff, R. M., \& Hirsh-Pasek. K. (2012). How reading books fosters language development around the world. Child Development Research, 2012 Article ID 602807, 15 pages. http://dx.doi.org/10.1155/2012/602807

Dickinson, D. K., McCabe, A., Anastasopoulos, L., Peisner-Feinberg, E. S., \& Poe, M. D. (2003). The comprehensive language approach to early literacy: The interrelationships among vocabulary, phonological sensitivity, and print knowledge among preschool-aged children. Journal of Educational Psychology, 9, 465-481. http://dx.doi.org/10.1037/0022-0663.95.3.465

Eskey, D. E. (1986). Theoretical foundations. In F. Dubin, D. E. Eskey \& W. Grabe (Eds.), Teaching second language reading for academic purposes (pp. 3-23). Reading, MA: Adison-Wesley.

Freebody, P., \& Anderson, R. C. (1983). Effects on text comprehension of differing proportions and locations of difficult vocabulary. Journal of Reading Behavior, 15(3), 19-39.

Gee, J. P. (2004). Situated language and learning: A critique of traditional schooling. New York NY: Routledge.

Griffin, T. M., Hemphill, L., Camp, L., \& Wolf, D. P. (2004). Oral discourse in the preschool years and later literacy skills. First Language, 24, 123-147. http://dx.doi.org/10.1177/0142723704042369

Harrison, C. (2004). Understanding reading development. London: Paul Chapman.

Heath, S. B. (1983). Ways with words. Cambridge: Cambridge University Press.

Hughes M., \& Westgate, D. (1998). Possible enabling strategies in teacher-led talk with young pupils. Language and Education, 12, 174-191. http://dx.doi.org/10.1080/09500789808666747 
Huttenlocher, J., Vasilyeva, M., \& Shimpi, P. (2004). Syntactic priming in young children. Journal of Memory and Language, 50, 182-195. http://dx.doi.org/10.1016/j.jml.2003.09.003

In H. W. Catts \& A, G, Kamhi (Eds.), Language and reading disabilities ( $2^{\text {nd }}$ ed. pp. 157-232). Boston: Allyn \& Bacon.

Leu, D. J., Jr. (1982). Differences between oral language and written discourse and the acquisition of reading proficiency. Journal of Reading Behavior, 14, 111-125.

Lever, R., \& Sénéchal, M. (2011). Discussing stories: On how a dialogic reading intervention improves kindergartners' oral narrative construction. Journal of Experimental Child Psychology, 108, 1-24. http://dx.doi.org/10.1016/j.jecp.2010.07.002 PMid:20828708

National Early Literacy Panel. (2009). Developing Early Literacy: Report of the National Early Literacy Panel. Jessup, Maryland, National Institute for Literacy. http://incs.ed.gov/publications/pdf/NELPReport09.pdf

NICHD Early Child Care Research Network (2005). Pathways to Reading: The Role of Oral Language in the Transition to Reading, Developmental Psychology, 41, 428-442. http://dx.doi.org/10.1037/0012-1649.41.2.428

Noonan, D. (1999). Bernard O'Brien's tooth. Wellington: Learning Media.

Palincsar, A. S. (1998). Social constructivist perspectives on teaching and learning. Annual Review of Psychology, 49, 345-375. http://dx.doi.org/10.1146/annurev.psych.49.1.345 PMid:15012472

Paris, A. H., \& Paris, S. G. (2003). Assessing narrative comprehension in young children. Reading Research Quarterly, 38, 36-76. http://dx.doi.org/10.1598/RRQ.38.1.3

Parkin, C., Parkin, C., \& Pool, B. (2002). PROBE reading assessment. New Zealand: Triune Initiatives.

Pearson, P. D., Hiebert, E. H., \& Kamil, M. L. (2007). Vocabulary assessment: what we know and what we need to learn. Reading Research Quarterly, 42, 282-296. http://dx.doi.org/10.1598/RRQ.42.2.4

Perfetti, C. A. (1990). The cooperative language processes: Semantic influences in an autonomous syntax. In D. A. Balota, G. B. Flores D'Arcais \& K. Rayner (Eds.), Comprehension processes in reading (pp. 205-230). Hillsdale, N.J: Lawrence Erlbaum Associates.

Raban, B. (1999). Language and literacy as epistemology. In J. S. Gaffney \& B. J. Askew (Eds.), Stirring the waters: The influence of Marie Clay (pp. 99-111). Portsmouth, NH: Heinemann.

Raban, B. (2000). Just the beginning. Canberra: Research and Evaluation Branch, International Analysis and Evaluation Division, Department of Education, Training and Youth Affairs.

Richgels, D. J. (2004). Paying attention to language. Reading Research Quarterly, 39, 470-477. http://dx.doi.org/10.1598/RRQ.39.4.6

Riley, J., \& Burrell, A. (2007). Assessing children's oral storytelling in their first year of school. International Journal of Early Years Education, 15, 181-196. http://dx.doi.org/10.1080/09669760701289136

Rumelhart, D. E. (1994). Toward an interactive model of reading. In R. B. Ruddell, M. R. Ruddell \& H. Singer (Eds.), Theoretical models and processes of reading (4th ed. pp. 864-894). Newark, DE: International Reading Association.

Scull, J. (2010). Embedding comprehension within reading acquisition processes. Australian Journal of Language and Literacy. 33, 87-107.

Singer, H. (1994). The substrata-factor theory of reading. In R. B. Ruddell, M. R. Ruddell \& H. Singer (Eds.), Theoretical models and processes of reading (4th ed. pp. 895-927). Newark, DE: International Reading Association.

Snow, C. E. (1991). The theoretical basis for relationships between language and literacy development. Journal of Research in Childhood Education, 6, 5-15. http://dx.doi.org/10.1080/02568549109594817

Snow, C. E., Burns, M. S., \& Griffin, P. (Eds.) (1998). Preventing reading difficulties in young children. Washington, DC: National Academy Press.

Stanovich, K. E. (1986). Matthew effects in reading: some consequences of individual differences in the acquisition of literacy. Reading Research Quarterly, 21, 360-406. http://dx.doi.org/10.1598/RRQ.21.4.1 
Stevens, R. J., Van Meter, P., \& Warcholak, N. D. (2010). The effects of explicitly teaching story structure to primary grade children. Journal of Literacy Research, 42, 159-198. http://dx.doi.org/10.1080/10862961003796173

Tabors, P. O., Snow, C. E., \& Dickinson, D. K. (2001). Homes and schools together: Supporting language and literacy development. In D. K. Dickinson \& P. O. Tabors (Eds.), Beginning literacy with language (pp. 313-334). Baltimore: Brookes Publishing.

Tracey, D. H., \& Morrow, L. M. (2006). Lenses on reading: An introduction to theories and models. New York: The Guilford Press.

Vasilyeva, M., \& Waterfall, H. (2012). Beyond syntactic priming: Evidence for activation of alternative $\begin{array}{lllll}\text { syntactic structures. Journal of Child Language, 39, } & \text { 283. }\end{array}$ http://dx.doi.org/10.1017/S0305000911000055

Vasilyeva, M., Huttenlocher, J., \& Waterfall, H. (2006). Effects of language intervention on syntactic skill levels in preschoolers. Developmental Psychology, 42, 164-174. http://dx.doi.org/10.1037/0012-1649.42.1.164

Vellutino, F. R., Tunmer, W. E., Jaccard, J. J., \& Chen, R. (2007). Components of reading ability: Multivariate evidence for a convergent skills model of reading development. Scientific Studies of Reading, 11, 3-32.

Vygotsky, L. S. (1978). Mind in society: The development of higher psychological processes. Cambridge: Harvard University Press.

Westby. C. E. (2005). Assessing and remediating text comprehension problems.

Woodcock, R. W. (1991). Woodcock language proficiency battery - revised, Chicago: The Riverside Publishing Company. 